\title{
LORD DENNING AND JUDICIAL ACTIVISM ${ }^{*}$
}

\author{
The Hon. Justice Michael Kirby A.C. C.M.G. ${ }^{* *}$
}

\section{YOUTHFUL HEROES}

Youth seeks out heroes: guides to show the way through life. When I was a student at the University of Sydney in the early 1960s, I had two judicial heroes: Sir Owen Dixon, Chief Justice of Australia, and Lord Denning, Master of the Rolls. ${ }^{1}$

The austere Dixon could be seen at work if we slipped into the courtroom of the High Court of Australia when it sat in Sydney as part of the continental circuit in which the Justices then spent their days. I never saw Dixon at the Law School. He was a remote, reserved, even cadaverous looking man; but a great jurist. Denning, on the other hand, was warm and avuncular, conversational and apparently even interested in students. In the early 1960s, when he was about the age I now am, he attended a dinner given in his honour by the Sydney law students to mark his visit to Australia. At my request he signed an enlarged photograph which I presented to him for his autograph. I had it framed and it

\footnotetext{
* Parts of this contribution draw upon a paper given by the author to a conference of the American Bar Association in Hawaii in January, 1998 now published in 81 A.J.S. Judicature 238 (1998) and, in an extended form, in (1998) 71 A.L.J. 599.

Justice of the High Court of Australia.

${ }^{1}$ Lord Denning was appointed Master of the Rolls on 19th April, 1962. For some Australasian reviews of his life see: I. Holloway, "Lord Denning: A Life" - Book Review (1994) 13 Uni. Tas. L. Rev. 194; B. McSherry, "Some Observations on the role of Lord Denning in the development of international law" (1984) 14 M.U.L.R. 721; A. Grant, "Lord Denning: An Appreciation" [1984] N.Z.L.J. 358; C.E.F. Ricket, "Lord Denning - Sincere Man and Problematic Judge" (1982) 10 N.Z.U.L. Rev. 91; L. Waller, "Bold Spirit" (1982) 56(8) Law Inst. J. (Vic.) 564; “Denning's Legal Philosophy” [1982] N.Z.L.J. 236; Lord Denning's Retirement (1982) 56 A.L.J. 443.
} 


\section{DENNING LAW JOURNAL}

has accompanied me on my journey since those days. From solicitor to barrister. From law reformer through the national industrial tribunal and the Federal Court of Australia. From the Presidency of the Court of Appeal of New South Wales which, like Denning, I regarded as a "mainspring of innovation"2 to my chambers in the High Court of Australia where I am now writing this essay. If ever I was in doubt about the path of justice or almost faltered in a resolve to cure injustice when it was in my power to do so, I had only to look at Denning's photograph to feel a renewed energy.

My two heroes had different perceptions about the role of the judge. Sir Owen Dixon propounded a rule of submission to the legislature's valid statutes and established legal authority. This fitted well the notion of parliamentary sovereignty. It coincided with the high measure of self-satisfaction that existed in the common law in the middle of this century: in the last Indian summer of British global power. When he took the oath of Chief Justice of Australia in 1952, Dixon said, in words known to every Australian law student of that era:

"Close adherence to legal reasoning is the only way to maintain the confidence of all parties in federal conflicts. It may be that the Court is thought to be excessively legalistic. I should be sorry to think that it is anything else. There is no other safeguard to judicial decisions in great conflicts than a strict and complete legalism." 3

Later, in an address to Yale University in the United States in 1955, the year I finished high school, Dixon accepted that judges developed the law. But he emphasised that judicial creativity operated within severe boundaries which imposed strict limitations:

"It is one thing for a court to seek to extend the application of accepted principles to new cases or to reason from the more fundamental of settled legal principles to new conclusions or to decide that a category is not closed against unforeseen circumstances which might be subsumed thereunder. It is an entirely different thing for a judge, who is discontented with the

\footnotetext{
${ }^{2}$ Lord Hailsham of St. Marylebone, Lord Chancellor, Valedictory Speech on the retirement of the Master of the Rolls [1986] Denning L. J. 8 at p. 9.

${ }^{3}$ (1952) 85 C.L.R. xi at xiv.
} 


\section{LORD DENNING AND JUDICIAL ACTIVISM}

result held to flow from a long accepted legal principle, deliberately to abandon the principle in the name of justice or of social necessity or of social convenience."

This was the orthodoxy taught to law students on the other side of the world from that in which Lord Denning was at work in the Court of Appeal in London. Imagine the surprise, then, in a generation of fresh Australian acolytes, to pick up Denning's opinions and to read there a clear counterpoint to Sir Owen Dixon's words of restraint and caution. Take for example the passage in Candler v. Crane, Christmas and $\mathrm{Co}^{5}$ There, in a famous dissenting judgment in the Court of Appeal, Denning, before he took the central seat, lamented the calamitous exception in the law of negligence which relieved many professional advisers from actions for damages for losses caused by a negligent, as distinct from fraudulent, misrepresentation:

"This argument about the novelty of the action does not appeal to me in the least. It has been put forward in all the great cases which have been milestones of progress in our law. In each of these cases the judges were divided in opinion. On the one side there were timorous souls who were fearful of allowing a new cause of action. On the other side there were the bold spirits who were ready to allow it if justice so required. It was fortunate for the common law that the progressive view prevailed."

Prevail it ultimately did when Denning's dissent of 1951 became the rule in England ${ }^{7}$ and was later adopted in other jurisdictions of the common law, including Australia. ${ }^{8}$

${ }^{4}$ O. Dixon, "Concerning the Judicial Method" (1956) 29 A.L.J. 468 at p.472. See also Kitto J. another great Australian judge of the same tradition, in Rootes v. Shelton (1967) 116 C.L.R. 383 at 386-387 administering a rebuke to Jacobs J.A. in Rootes v. Shelton (1966) 86 W.N. (N.S.W.) (Pt.1) 101 at 102. Cf. Clunies-Ross v. The Commonwealth (1984) 155 C.L.R. 193 at 204; J. J. Doyle, "Judicial Lawmaking - Is Honesty. the Best Policy?" (1995) 17 Adel. L. Rev. 161 at p.203; and F.G. Brennan, "The Parliament, the Executive and the Courts: Roles and Immunities" (1997) 9 Bond L. Rev. 136 at pp.139-140.

${ }_{6}^{5}$ [1951] 2 K.B. 164.

${ }^{6}$ Ibid at p. 178 .

${ }^{7}$ Hedley Byme and Co. Ltd. v. Heller and Partners Ltd. [1964] A.C.465.

${ }^{8}$ Mutual Life and Citizens Assurance Co. v. Evatt [1971] A.C. 793; (1970) 122 C.L.R. 628 (P.C.). 


\section{DENNING LAW JOURNAL}

There have always been in the law, as in life, Dixons and Dennings. The expositors of settled doctrine. The reformers who push doctrine forward: inventing new categories, reformulating concepts, extending the frontiers, advancing with an energy derived from the perceived needs of justice. Different ages tend to produce, and to elevate to the ascendancy, judges whose inclinations are akin to those of Dixon or those of Denning. That is why we see, in an historical review of the history of the common law, periods of creativity and energy; often followed by longer periods of consolidation and complacency.

Lord Hailsham of St. Marylebone, Lord Chancellor at the time of Lord Denning's retirement, suggested that his arrival at the English Court of Appeal had coincided with the conclusion of a period of thirty-five years following which he said:

"Our Lady of the Common Law awoke from her slumbers and entered upon a period of renewed creativity, generated no doubt by the vast social and legislative changes which have overtaken us, and inspired by a desire to do right to all manner of people without fear or favour, affection or ill-will in the changed circumstances of the post-War world."

Sometimes, a judge may begin a career on the bench evidencing strong resistance to judge-made law but later embrace perceived obligations of creativity and legal advance with astonishing enthusiasm. ${ }^{10}$ Some judges have been known to preach one doctrine consistently; but when a matter most closely touches a fundamental issue of justice important to them, to practise another. In particular areas of the law (such as equity) refinement and elaboration of principles by the judges has never suffered from the "quaint common law fiction that the rules of equity had survived from time immemorial and that the judges merely find and declare the pre-existing law."

${ }^{9}$ Lord Hailsham, supra n. 2 at p.8.

${ }^{10}$ M.D. Kirby, "A.F. Mason - From Trigwell to Teoh" (1997) 20 M.U.L.R. 1087.

$"$ A. F. Mason, Foreword to P. Parkinson, The Principles of Equity (L.B.C. Information Services, 1996) at p.vi. See Re Hallett's Estate (1878) 13 Ch. D. 696. Lister v. Romford Ice and Cold Storage Co. Ltd. [1957] A.C. 555 at 592 per Lord Radcliffe and Wik Peoples v. Queensland (1996) 187 C.L.R. 1 at 179 per Gummow J. cf. Garcia v. National Australia Bank Limited (1998) 155 A.L.R. 614 at 626. 


\section{LORD DENNING AND JUDICIAL ACTIVISM}

sometimes true that particular areas of the law are more susceptible to judicial revision and re-expression than others.

Commentators are sometimes critical of judicial attempts in the particular area of their own concern - as if things they teach or have mastered should be left alone by impious hands. One commentator on Lord Denning's work in the area of equity and trusts has suggested that, although his impact had been considerable, his judgments had been less well received in that domain, say than in contract and tort. ${ }^{12}$ It was suggested that this was because equity and trusts deal with property law where it is usually desired to have "settled and clearly defined principles" in preference to "vague, flexible concepts." But in so many areas of public and private law, Lord Denning brought fresh insights and impatience with blind adherence to old formulations of the law where these appeared out of harmony with a sense of the just result of the particular case. ${ }^{13}$

When Lord Denning urged a new approach to statutory interpretation, ${ }^{14}$ he attracted the censure of the London Times editorialist, in those days immovably orthodox:
"What Lord Denning is trying to do is to import into the interpretation of statutory provisions the same degree of judicial creativity as is normally applied to developing the common law. The tradition of English law does not support that approach. It may be acceptable to

\footnotetext{
${ }^{12}$ D. J. Hayton's assessment of Lord Denning's work in the area of Equity and Trusts appears in J. L. Jowell and J. P. W. B. McAuslan (eds.), Lord Denning - The Judge and the Law, (Sweet and Maxwell, 1984), reviewed [1986] Denning L. J. 129 at p.130.

${ }^{13}$ Lord Denning identified as amongst his most important innovations in judge-made law his decisions on the scope of negligence in Candler v. Crane, Christmas and Co. supra n.5; the extension of the remedy of prerogative writs to errors of law in $R$. v. Northumberland Compensation Appeal Tribunal ex parte Shaw [1952] 1 K.B. 338 and the provision of declaratory relief: Bamard v. National Dock Labour Board [1953] 2 Q.B. 18; his decisions on exception clauses in contract: George Mitchell Ltd. v. Finney Lock Seeds [1983] Q.B. 284 and his revision of cases affecting the status of woman: Bendall v. McWhirter [1952] 2 Q.B. 466 and Rimmer v. Rimmer [1953] 1 Q.B. 63. He introduced the Mareva injunction in the case of Rasu Maritima S.A. v. Persahaan [1978] Q.B. 644 (see also Mareva Compania Naviera S.A. v. International Bulkcarriers Ltd. [1975] 2 Lloyd's Rep. 509). He also pushed forward the influence of international law upon English municipal law. See Foreword [1986] Denning L.J. at 1-3.

${ }^{14}$ R. v. Sheffield Crown Court ex parte Brownlow [1980] Q.B. 530 at 539 . His approach on this topic is now accepted and applied in Australia: see generally Kingston v. Keprose Pty. Ltd. (1987) 11 N.S.W.L.R. 404 at 423-424; approved by the High Court in Bropho v. Westem Australia (1990) 171 C.L.R. 1.
} 
introduce a qualified element of equity into the harsh rules of statutory construction. [But] this would be under his formula for the majority of judges to determine a sensible result. That would be to usurp Parliament's function and give judges a power which the vast majority of them neither seek nor are capable of exercising." 15

It is interesting today to compare the restrained comment of the editorialist with the language of obsequy which is the common diet of Lord Denning's judicial success.

\section{JUDICIAL OBEDIENCE}

Of one point Lord Denning was always insistent. It was the central importance of the rule of law. He demanded that everyone, including public officials ${ }^{16}$ and powerful unions ${ }^{17}$ comply with the law:

"The law should be obeyed. Even by the powerful. Even by the Trade Unions. We sit here to carry out the law. To see that the law is obeyed. And that we will do. A subject cannot disregard the law with impunity. To every subject in this land, no matter how powerful, I would use Thomas Fuller's words over three hundred years ago 'Be you ever so high, the law is above you.",'18

Every judge, be he ever so high, is also subject to the discipline of the law. It would be corrosive of the rule of law, and destructive of obedience to the law, if judges did not themselves conform to, and uphold, clearly settled rules of law. This was the complaint leveled against Lord Denning when in Broome v. Cassell and $\mathrm{Co}^{19}{ }^{19}$ he declined to follow the holding of the House of Lords in Rookes v. Barnard ${ }^{20}$ to the effect that punitive and exemplary damages should be confined to certain restrictive categories of cases. Lord Denning gave four reasons for refusing to follow the principles laid down by the Lords. These were that the common law on the subject had been so well settled before 1964 and

\footnotetext{
${ }^{15}$ The Times 3th March, 1980.

${ }^{16}$ See generally D.G.T. Williams, "Lord Denning and Open Government" [1986] Denning L.J. 117.

${ }^{17}$ Gouriet v. Union of Post Office Workers [1977] 2 W.L.R. 310 reversed [1978] A.C. 435.

${ }^{18}$ Ibid at p.331.

${ }^{19}$ [1971] 2 Q.B. 354.

20 [1964] A.C. 1129 at 1226-1227 per Lord Devlin.
} 


\section{LORD DENNING AND JUDICIAL ACTIVISM}

that it was not open to the House of Lords to overthrow it; that counsel who had appeared had not argued the point before the Lords and indeed had accepted that the common law was as it was then understood; that contrary to what Lord Devlin had said in the House of Lords there were two previous decisions of the Lords approving awards of exemplary damages; and that the doctrine which had been propounded was "hopelessly illogical and inconsistent.".21

Not unsurprisingly, the opinion provoked a severe Lordly reproof. ${ }^{22}$ The Lord Chancellor recorded the suggestion by Lord Denning that the earlier opinion of the House of Lords had been expressed per incuriam and even ultra vires and was unworkable and should not be followed. He said that the "propriety and desirability" of the course taken by the Court of Appeal was raised for comment by their Lordships. And then, with "studied moderation," the Lord Chancellor went on:

"If the Court of Appeal felt, as they were entitled to do, that in the light of the Australian and other Commonwealth decisions

Rookes v.Barnard ought to be looked at again by the House of Lords ... they were perfectly at liberty to say so. More, they could have suggested that so soon as a case at first instance arose in which the ratio decidendi of Rookes v. Barnard was unavoidably involved, the parties concerned might wish to make use of the so-called "leapfrogging" procedure now available to them .... Moreover, it is necessary to say something of the direction to judges of first instance to ignore Rookes v. Barnard as 'unworkable'.... [I]n my view ... it is not open to the Court of Appeal to give gratuitous advice to judges of first instance to ignore decisions of the House of Lords ... and if it were open to the Court of Appeal to do so it would be highly undesirable. The course taken would have put judges of first instance in an embarrassing position, as driving them to take sides in an unedifying dispute between the Court of Appeal ... and the House of Lords. But, much worse than this litigants would not have known where they stood. ... Whatever the merits, chaos would have reigned until the dispute was settled, and in legal matters, some degree of certainty is at least as valuable a part of justice as perfection. ... The

${ }^{21}$ Supra n.19 at p.381.

${ }^{22}$ Broome v. Cassell [1972] A.C. 1027 (H.L.). See discussion in J. Stone, "Double Count and Double Talk - The End of Exemplary Damages" (1972) 46 A.L.J. 311. 


\section{DENNING LAW JOURNAL}

fact is, and I hope it will never be necessary to say so again, that, in the hierarchical system of courts which exist in this country, it is necessary for each lower tier, including the Court of Appeal, to accept loyally the decisions of the higher tiers." ${ }^{23}$

It is not unusual in a hierarchical court system, for differences to arise about the state of judicial authority and the binding rule to which lower courts must submit themselves. When I was President of the New South Wales Court of Appeal I was, from time to time, the subject of reversals delicately worded criticisms where it was thought that I had, without warrant, pushed the law beyond the limits of settled authority. ${ }^{24}$ In due course, in my new role, I may some day have opportunities to return to these cases. Sometimes, intermediate courts, for their part, gently castigate those placed above them for failing to offer clear guidance on an important matter of practice ${ }^{25}$ or for failing to clarify the status of a legal rule thought to be overtaken by events and uncertain as to its binding force. ${ }^{26}$ But it is rare to see such a judicial exchange as appeared in the succeeding decisions in Broome v. Cassel.

In the great theatre of English law, one suspects that the storm that brewed and then settled caused no ultimate offence. At the valedictory ceremony for Lord Denning's retirement ten years later, the same Lord Chancellor claimed with mock humility, that the Court of Appeal was "not quite infallible" and that "unless it becomes so, there will always be a humble purpose left for the

\footnotetext{
${ }^{23}$ Ibid at pp.1053-1054.

${ }^{24}$ See e.g. Public Service Board of N.S.W. v. Osmond (1986) 159 C.L.R. 656 at 662 (per Gibbs C.J.) reversing Osmond v. Public Service Board of N.S.W. [1984] 3 N.S.W.L.R. 447 (the common law right to reasons from an administrator - in which I followed Lord Denning M.R.'s dissenting judgment in Breen v. Amalgamated Engineering Union [1971] 2 Q.B. 175 at 190-191). And Lamb v. Cotogno (1987) 164 C.L.R. 1 affirming the majority in Cotogno v. Lamb [No. 3] (1986) 5 N.S.W.L.R. 559 (the adaptation of the recoverability of exemplary damages in the context of a compulsory third party insurance statutory scheme).

${ }^{25}$ See e.g. R. v. R. McK. Fraser, (1998) 10 Judicial Officers' Bulletin 56A in which it was stated that no ratio decidendi could be discovered in the majority opinions of the High Court of Australia in Gipp v. The Queen (1998) 72 A.L.J.R. 1012 (concerning the admissibility of propensity evidence in trials of sexual offences). In such circumstances trial judges were advised to follow pre-existing authority.

${ }^{26}$ See e.g. Garcia v. National Australia Bank Limited (1998) supra $\mathrm{n} .11$ at 630-633 concerning the suggestion that the Court of Appeal (N.S.W.) had not conformed to the authority of the High Court of Australia in Yerkey v. Jones (1939) 63 C.L.R. 649 cf. Barclays Bank plc v. O'Brien [1994] 1 A.C. 180 at 194-195 which rejected Yerkey.
} 


\section{LORD DENNING AND JUDICIAL ACTIVISM}

Appellate Committee of the House of Lords." ${ }^{\text {"27 }}$ Some people thought that Denning made a mistake in responding to Lord Kilmuir's request that he go back from the House of Lords to be Master of the Rolls. But Denning did not agree. He explained that he would "much rather be in the place where I've got some influence on the development of the law.",28

Influence is one thing. Denning wielded it with the assurance of a "supremely able person." 29 But defiance of, and disobedience to, clear legal authority is impermissible to anyone. Least of all does it become a judge who is a servant of the law. This said, there remains in many cases a large zone of decision-making in which judges must make choices. Few today, at least within the judiciary and the legal profession, contradict this proposition. ${ }^{30}$ The concept of the judge as a kind of jumbo-jet captain, always flying on automatic pilot, might be acceptable to some old-fashioned citizens and media commentators who prefer not to know the unsettling realities. But in this century, the myth of the automatic pilot was shattered most vividly by the creative example of Lord Denning. The ghost was finally laid to rest by that other great judge of Denning's time, Lord Reid, who declared that the notion that a judge merely declared the law was a "fairytale" not to be seriously entertained by knowledgeable people. ${ }^{31}$

Written constitutions are specially ambiguous. Statutes are often obscure. In a time of rapid social and technological change, old common law precedents are sometimes silent or not really applicable to the legal problem in hand. Resolving the ambiguities, repairing the obscurities and filling the gaps, judges inescapably have a creative role. The perception of opportunities for creativity, and the enthusiasm for the task, may differ between a Denning and a Dixon. But neither could ultimately escape such obligations. They are bound up in the very function of a judge in a common law system. The legitimate debate concerns the candour with which such choices should be acknowledged, the forensic tools which should be provided to help in their resolution and the occasions in which the judge should act or hold back and leave legal development to the elected Parliament.

\footnotetext{
27 Supra n.2.

${ }^{28}$ Lord Denning, "This is my Life" [1986] Denning L.J. 17 at p.26.

${ }^{29}$ Lord Justice Kerr, interview with Hugo Young, Talking Law, B.B.C., 16th September, 1979, 12

${ }^{30}$ See e.g. M. H. McHugh, "The Lawmaking Function of the Judicial Process" (1988) 62 A.L.J 15 at p. 116 .

${ }^{31}$ Lord Reid, "The Judge as Lawmaker" (1972) 12 J.S.P.T.L. 22.
} 


\section{DENNING LAW JOURNAL}

\section{JUDICIAL “ACTIVISM" TODAY}

Since Lord Denning's long years of service as a judge of first instance, as a member of the House of Lords and as Master of the Rolls, the public debates concerning the role of the judiciary acting as Lord Denning clearly did, have become more intemperate and much more angry. In several countries, the issue has become one of active political and partisan debate. Let me review some of the developments in the past year or two which the judicial successors to Dixon and Denning in several countries, have had to face in the discharge of their judicial duties.

\section{United Kingdom}

In the United Kingdom, from whose judiciary common law countries ultimately derive their model, the deference paid to judges has clearly declined since Lord Denning served amongst them. The present Lord Chancellor, then in political opposition, called attention, in a speech in the House of Lords in June,1996, to "unprecedented antagonism" occasioned by what he described as "a major clash over the distinct roles of parliament, ministers and the judges." ${ }^{32} \mathrm{He}$ condemned "judicial invasion of the legislature's turf.",33 He called the judges of the United Kingdom back to A. V. Dicey's submission to the absolute supremacy of Parliament.

The media of Britain fell upon the differences which emerged between the last British government and the senior judiciary, taking "delight in both highlighting - and, one suspects, fuelling - the split between judiciary and government." ${ }^{34}$ The Beaverbrook press claimed that there was a "sickness sweeping through the senior judiciary - galloping arrogance." ${ }^{35}$ With just a little hubris, the editorialist declared that "[w]hile European Human Rights judges, some from countries which once sent political prisoners to Siberia, are venting their spleen on Britain, legal weevils here at home are practising their own brand of mischief." ${ }^{36}$ The Rothermere press joined in with comments that seem

${ }^{32}$ Lord Irvine of Lairg, H.L. Deb. vol. 572 col. 1254 (5th June, 1996).

${ }^{33}$ Ibid at col.1255.

${ }^{34}$ R.Stevens, "Judges, Politics, Politicians and the Confusing Role of the Judiciary" in

K. Hawkins (ed.) The Human Face of Law, (Clarendon Press, 1997), at p.264.

${ }^{35}$ The Daily Express, 4th November, 1995, cited Stevens, ibid.

${ }^{36}$ The Sunday Express, 1st October, 1995. 


\section{LORD DENNING AND JUDICIAL ACTIVISM}

astonishing to lawyers of the United States and Australia, brought up in the tradition of constitutional judicial review:

"Now it seems that any judge can take it on himself to overrule a Minister, even though Parliament might approve of the Minister's action. This is to arrogate power to themselves in a manner that makes a mockery of Parliament. ... The judges are giving the impression that they are acting on a political agenda of their own." 37

The Times, once apparently a bastion of the establishment in Britain, under new management, demanded that a new Chief Justice be appointed for England who could "steer his profession away from the sound of gunfire."38

The more courageous and articulate members of the English judiciary, such as Sir Stephen Sedley, answer back. They remind those who have forgotten about the perils of supine judges. They call in aid Sir Edward Coke's assertion of the sovereignty of the courts in the face of the Crown's prerogatives. ${ }^{39}$ They caution against mob rule. Increasingly, they draw on the experience of the United States for the refurbishment of the constitutional institutions of Britain. ${ }^{40}$ Sometimes their leaders rise in the House of Lords, as Lord Denning did in retirement from time to time, to defend the judiciary from attack and to espouse its causes. ${ }^{41}$ Because of our conception of the separation of powers, such a facility is unavailable to judges in the United States and Australia. The forums available to us are rather more limited.

\section{New Zealand}

In New Zealand too, in recent times, the deference of the past has also taken a battering. Judges have been castigated ferociously for bail decisions which went wrong. They have been prosecuted for false travel claims. They have been

${ }^{37}$ The Daily Mail, 2nd November, 1995.

${ }^{38}$ The Times, 4th May, 1996.

${ }^{39}$ Sir Stephen Sedley, "Human Rights: A 21 st Century Agenda" in R. Blackburn and J. J.

Busuttil et al, Human Rights for the 21 st Century, (Pinter, 1996), at p.1. Cf. Lord Ackner, "The Erosion of Judicial Independence" [1996] N.L.J. 1289.

${ }^{40}$ Lord Steyn, "The Weakest and Least Dangerous Department of Govemment" [1997] P.L. 84.

${ }^{41}$ A recent example is Lord Bingham L.C.J., H.L. Deb. vol.582 col.1245 (3rd November, 1997). 


\section{DENNING LAW JOURNAL}

attacked for failing to respond to media criticism. The Chief Justice of New Zealand, in a public speech, cautioned against:

"The increasingly strident cries of the well heeled sector of the community, pressuring Government and the judiciary as to the particular brand of justice they seek, are not a pretty sight either, nor are the supportive noises made by acolytes in the profession." ${ }^{42}$

He was denounced in the New Zealand Law Journal, of all places, for getting into politics, damaging the independence of the judiciary and insulting the legal profession.

\section{Australia}

The debates in Britain and New Zealand seem positively genteel by comparison to those which have engaged the Australian judiciary in the past year or so. The problem is a general one. But it came to the fore after the High Court of Australia decided, in December, 1996, that native title to land of the indigenous peoples of Australia was not, as a matter of law, necessarily extinguished by the pastoral leases granted by the Crown and under statute over vast areas of the Australian continent, beginning in the 19 th century. ${ }^{43}$

The decision was by a majority of four to three of the Justices of the seven member High Court. ${ }^{44}$ As a result, politicians in both Federal and State Parliaments appeared to compete with each other in attacking the Court, and especially the majority judges. Few demonstrated familiarity with what the judges had actually written. A senior Federal Minister singled my reasons out for special castigation, declaring that he was "underwhelmed" by them. A State Premier described them as nothing more than "rantings and ravings." The attacks, the like of which we have never seen before in Australia, continued for months. The Federal Attorney-General stated that he did not agree with the convention that the Attorney-General should defend the courts from criticism.

${ }^{42}$ Sir Thomas Eichelbaum cited in "Judges and Politics" [1996] N.Z.L.J. 361 at p.361. See also Editorial, "Dismissal of Judges" [1997] N.Z.L.J. 333.

${ }^{43}$ The Wik Peoples v. Queensland supra n.11. See also Mabo v. Queensland [No. 2] (1992) 175 C.L.R. 1.

${ }^{44}$ Toohey, Gaudron, Gummow and Kirby JJ.; Brennan C.J., Dawson and McHugh JJ. dissenting. 


\section{LORD DENNING AND JUDICIAL ACTIVISM}

Courts must, he declared, find ways of defending themselves. ${ }^{45}$ For this, he, in turn, was criticised by judges and retired judges. ${ }^{46}$ The politicians maintained their attack. Some do to this day; although the storm appears to have abated somewhat.

The derogatory comments of politicians soon became the spring-board for academic and media castigation. High Court decisions, the Court and the justices were labelled "bogus," "pusillanimous and evasive," guilty of "plunging Australia into the abyss," a "pathetic ... self-appointed [group of] Kings and Queens," a group of "basket-weavers," "gripped ... in a mania for progressivism," purveyors of "intellectual dishonesty," unaware of "its place," "adventurous," needing a "good behaviour bond," needing, on the contrary, a sentence to "life on the streets," an "unfaithful servant of the Constitution," "undermining democracy," a body "packed with feral judges," "a professional labor cartel." There were many more epithets of a like character, many even more unkind.

These attacks eventually called forth defences of the High Court of Australia from judges and retired judges, the organised legal profession, leading members of the Bar, a former Governor-General, legal academics, a few members in Parliament, selected editorialists and even a law student. One professor warned of the consequences of such a prolonged confrontation between executive government and the judiciary in Australia. He did so on the basis of the experiences of the land of his birth, Malaysia, when, in 1988, the highest judge was driven from office when he fell out of political favour. ${ }^{47}$ In an unusual move, the then Chief Justice of Australia wrote a private letter to the Acting Prime Minister to correct the erroneous suggestion, made publicly, that the Court had deliberately delayed its decision in the pastoral leases case.

Promptly, this letter was secured by journalists (presumably knowledge of its existence was leaked in Parliament) under the Freedom of Information Act. It was given widespread publicity. ${ }^{48}$ Later, at a series of legal conferences in

${ }^{45}$ D. Williams, "Judicial Independence and the High Court" (1998) 27 U.W.A. L. Rev. 140 at p. 150 .

${ }^{46}$ See for example Sir Gerard Brennan, "State of the Australian Judicature" (1998) 72 A.L.J. 33 at p. 41.

${ }^{47}$ Professor Hoong Phun Lee, "Why we must protect the protectors" Sydney Morning Herald, 13th June, 1997 at 17.

${ }^{48}$ Noted in A. Ramsay, "High Court gets short shrift" Sydney Morning Herald, 8th March, 1997 at 43. 
Australia ${ }^{49}$ and overseas, ${ }^{50}$ the Chief Justice spoke of the dangers of such sustained attacks on the judiciary. In October 1997 Chief Justice Gleeson, since then succeeding to the office of Chief Justice of Australia but then Chief Justice of New South Wales called for a truce and for mutual respect between the branches of government. ${ }^{51}$

The feature of the Australian debate which has concerned many judges and lawyers has been the shift from the bipartisan political acceptance of constitutional and other decisions of the High Court which had marked Australia's history in the past, even when those decisions were extremely important and highly controversial. There is also a concern that such an unrelenting barrage of criticism and denigration would, if unabated, undermine the community's confidence in the courts and acceptance of court decisions. Editorialists might declare that "robust legal debate [is] good for [the] country." ${ }^{, 52}$ But a lot of judges and lawyers, unused to such unrelenting assaults, had their doubts.

\section{United States of America}

The prize for the worst examples in a developed country in this genre of political attack on the judiciary labelled "activist" must go to the United States of America. Of particular concern to outsiders (and doubtless to citizens as well) has been the appearance of federal political leaders, looking around for themes for their electoral campaigns, selecting the easy targets of the judiciary as a means of promoting themselves as "tough" on law and order issues. ${ }^{53}$

Senator Robert Dole's call for the impeachment of Judge Harold Baer of the United States District Court, following a much publicised ruling in a criminal trial, ${ }^{54}$ and his consignment of United States Appeals Judge Rosemary Barkett to his "judicial hall of shame"

${ }^{49}$ Sir Gerard Brennan, supra. n.46; $c f$. Chief Justice Brennan, Address to the Twelfth South Pacific Judicial Conference, noted Australian, 15th April, 1997 at 3; Sydney Morning Herald 15th April 1997 at 3.

${ }^{50}$ Address in Dublin, 23rd April, 1997 at 7.

51 A.M. Gleeson, "Who Do Judges Think They Are?" (1998) 22 Criminal Law Joumal 10.

${ }^{52}$ Weekend Australian, 15-16th February, 1997 at 22.

${ }^{53}$ S. B. Bright, "Political Attacks on the Judiciary" 80 Judicature 165 (1997). See also P.J. White, "An America Without Judicial Independence" 80 Judicature 174 (1997).

${ }^{54}$ Bright, ibid at p. 166 .

${ }^{55}$ lbid at p. 169. 


\section{LORD DENNING AND JUDICIAL ACTIVISM}

was pointed out that the good senator had voted to confirm 97 per cent of President Clinton's judicial nominees. However, the gravest attacks in the United States have been made by State politicians seeking to sanction judges for decisions in criminal, and particularly death penalty, cases which tend to engender the strongest public passions. The Governor of Tennessee (Mr. Don Sundquist), after effectively securing the removal of Justice Penny White from the Supreme Court of that State, by electoral recall, declared that judges should be looking over their shoulders to see whether the same would happen to them. ${ }^{56}$ This assertion drew the retort of Justice John Paul Stevens of the United States Supreme Court, speaking at the 1996 annual meeting of the American Bar Association.

"It was never contemplated that the individual who has to protect our individual rights would have to consider what decision would produce the most votes." 57

There have been a number of cases in other states of the United States. They include the removal of Chief Justice Rose Bird and two other Justices of the Supreme Court of California, and Justice James Robertson who was voted off the Mississippi Supreme Court in 1992..$^{58}$ The action of Judge Baer, in changing his ruling, after the heat of much political pressure was applied, may have been unconnected with that pressure. But it certainly did not look good. ${ }^{59}$

Fundamental human rights defend the right of every person in a cause affecting them to be heard by an independent, neutral and unbiased judge. The Declaration of Independence of the United States lists amongst the grievances against King George III that "He has made judges dependant on his Will alone, for the tenure of their offices ...." Constitutional decisions uphold the promise of judicial independence. ${ }^{61}$ It is also guaranteed in international law by the International Covenant on Civil and Political Rights. ${ }^{62}$ However, political

\footnotetext{
${ }^{56} \mathrm{Ibid}$ at p. 166 .

${ }^{57}$ lbid at p. 169.

${ }^{58} \mathrm{Ibid}$ at p. 170.

${ }^{59}$ Ibid at p. 172.

${ }^{60}$ Noted ibid at p. 172.

${ }^{61}$ In the United States see Chambers v. Florida, 309 U.S. 227 (1940) per Black J.. See also American Bar Association, An Independent Judiciary, 1997 at 9-12.

${ }^{62}$ International Covenant on Civil and Political Rights, Art. 14.1 "All persons shall be equal before courts and tribunals. In the determination of any criminal charge against him or of his
} 


\section{DENNING LAW JOURNAL}

pressure, applied with a fair measure of brutality, to secure particular results from sitting judges and to prevent the appointment of persons labelled "activist," undermines the principle of independent, neutral and impartial justice according to law. It is no more to be tolerated where the brutality is verbal than where it is physical.

One of the features of the United States attacks on the judiciary is the complete misrepresentation of judicial opinions and serious over-simplification of very complex issues. ${ }^{63}$ Another is the report of elected judges in the United States running for office or re-election on the boast that they are "too tough on criminals." "64 "Activism" has become a bogey-word for judges. In the current political climate, anyone so labelled will probably not get nominated, appointed or elected and, if the power exists, may get recalled or removed.

The detail about controversial cases tends to elude headstrong politicians on the campaign trail. A particular concern is the failure of leading political officer-holders in several countries to speak up, as formerly they did, to defend judicial independence. A United States commentator observed:

“... [t] hose in the Democratic Party should have taken President Clinton - a former constitutional law professor - to task for the suggestion that he might call for Baer's resignation because he disagreed with Baer's decision." 65

For anyone wanting to read the catalogue of United States equivalents to the list of verbal denigration recently hurled at the Australian judiciary, a good starting point is the article by Judge Joseph W. Bellacosa of the New York State Court of Appeals. "Screwballs" ${ }^{67}$ is one of the kindest of the epithets. Judge Bellacosa concludes:

rights and obligations in a suit at law, everyone shall be entitled to a fair and public hearing by a competent, independent and impartial tribunal established by law." Cf. Liteky v. United States 510 U.S. 540 at 555; 114 S. Ct. 1147 at 1157 (1994).

${ }^{63}$ Bright, supra $\mathrm{n} .53$ at p.173.

${ }^{64}$ The advertisement is reproduced in S. B. Bright, "Political Attacks on the Judiciary: Can Justice be Done Amid Efforts to Intimidate and Remove Judges from Office for Unpopular Decisions?" (1997) 72 N.Y. Uni. L. Rev. 308 at p. 323.

${ }^{65}$ Ibid.

${ }^{66}$ J .W. Bellacosa, "Remarks - Judging Cases v. Courting Public Opinion" 65 Fordham L.Rev. 2381 (1997).

${ }^{67}$ Ibid at p.2385. 


\section{LORD DENNING AND JUDICIAL ACTIVISM}

"Judges can take criticism, I am very confident, but whether the public interest can stand and absorb mal-informed, drum-beaten and heated attacks on the judicial process is worth pause and reflection." 68

\section{CONCLUSIONS}

What a contrast is seen in the laurels which Lord Denning gathered at the end of his judicial service. Few judges of the common law world have retired from office with more honours, and more genuine affection, than he enjoyed. Moreover, by the time of his retirement, he had become a hero, especially to young lawyers throughout the Commonwealth of Nations, far from his courtroom on the Strand in London. True, there were always critics. True also, some of his ventures into judicial law reform were disapproved of by the commentators. ${ }^{69}$ Occasionally they were slapped down by the House of Lords, as happened in Rookes v. Barnard. ${ }^{70}$ But how do we explain the different response to his work and the altered climate of today which I have described above?

The affection can perhaps be attributed to his extremely long service, his willingness to travel far and wide and to talk to audiences of scholars and students. His inimitable prose style, the like of which has rarely, if ever, been seen in the law reports also played a part. But the admiration sprang from his self-evident dedication to the cause of justice as he saw it, and to the extremely skilful techniques of lawyering which he brought to bear on the development of the common law and in the construction of ambiguous statutes so as to achieve results which to many, as to him, seemed manifestly necessary and just in the circumstances. He nailed his banner to the mast of legal reform. He gathered behind him, I would suggest, a majority of the lawyers of his generation and many citizens as well:

"What is the argument on the other side? On this, that no case has been found in which it has ever been done before. That argument does not appeal to me in the least. If we never do anything that has not been done before, we shall never get anywhere. The law will

${ }^{68}$ Ibid at p.2388.

${ }^{69}$ See e.g. D. J. Hayton's comments in Jowell and McAuslan, supra n.12.

${ }^{70}$ [1964] A.C. 1129. 


\section{DENNING LAW JOURNAL}

stand still while the rest of the world goes on; and that would be bad for both."

Even where Denning was rebuked by the House of Lords - ironically for standing out against an attempted "reform" by their Lordships of the principles governing punitive and exemplary damages - his instincts coincided with the feelings of judges in Australia, Canada and New Zealand who were likewise unconvinced by the attempted reform. Although some of Denning's views on personal and sexual morality have undoubtedly been overtaken by social events and more enlightened times ${ }^{72}$ and although his references to foreigners in his opinions sometimes displayed a kind of old-fashioned English xenophobia, ${ }^{73}$ his capacity to adjust quickly to new social and legislative conditions, and his willingness to be innovative in so many fields of law, attracted not general calumny (of the kind that I have illustrated from recent judicial experience in many jurisdictions) but appreciation, understanding and praise. Even the critics, and over the years there were many within the judiciary and legal profession, seemed to accept the need for an occasional vigorous shakeup of legal principles of the kind which Lord Denning regularly administered. The personal vituperation, threatening language and politicisation of targeted and personal attacks on judges as "activists" was almost wholly missing. Yet if ever there was a judicial "activist," it was Lord Denning. He would not have denied it. He would have been proud of the appellation. He would have said that it put him in the ranks of great common law judges of the past such as Lord Mansfield in England, John Marshall in the United States and Justices Isaacs, Evatt and Murphy in Australia. ${ }^{74}$

For Denning, creativity was part of the genius of the common law. Where else did the principles of the common law come from except the creative minds

\footnotetext{
${ }^{71}$ Packer v. Packer [1954] P. 15 at 22 per Denning L.J.

${ }^{72}$ Cf. Ward v. Bradford Corporation [1972] 70 L.G.R. 27. For comment see M.D. Kirby, "Lord Denning: An Antipodean Appreciation" [1986] Denning L. J. 102 at p.110.

${ }^{73}$ See e.g. Drain v. Evangelou [1978] 2 All E.R. 437 at 439; McCall v. Abelesz [1976] Q.B. 585 at 591; De Falco v. Crawley Council [1980] Q.B. 460 at 472 and comment [1986] Denning L. J. at 134.

${ }^{74}$ There have always been outspoken proponents of judicial restraint. In the United States, Felix Frankfurter in his later years especially, was foremost in the criticism of excessive judicial invention. ["If judges want to be preachers, they should dedicate themselves to the pulpit; if judges want to be primary shapers of policy, the legislature is their place"; $F$. Frankfurter, "John Marshall and the Judicial Function" in A.E. Sutherland (ed.) Government Under Law (Harvard University Press, 1956) at p. 31].
} 


\section{LORD DENNING AND JUDICIAL ACTIVISM}

of the judges of the past searching the casebooks for just solutions to new problems? Why, he constantly asked himself, was there a demand that, in this age, the element of creativity and development of legal principle should be dropped? The suggestion that this was so out of deference to an elected Parliament scarcely carried conviction for him. All too often, Parliament ignored the multifarious needs of law reform: its eyes fixed on the large political debates and the battles for office. Yet the pressures of change and the needs for reform were greater at this time than ever because of changing social, technological and governmental developments.

There have always been criticisms of judges and their decisions, as even the record of Lord Denning's life illustrates. Some criticisms are justified. Some complaints can now be directed into new channels by which, in many jurisdictions, complaints against judges can now be formally ventilated. ${ }^{75}$ But the stridency and political character of recent attacks on the judiciary of the common law suggests an urgent need to explain to politicians, to the media and to citizens alike what judges do and how the common law system actually operates.

We need a modern Denning with great experience and skills of communication, to rise above the chorus of publicised opprobrium. And to explain that the element of creativity, properly harnessed and well directed, is not a weakness of the common law system. It is a mighty strength. It helps to explain the survival of the common law as one of the greatest of the legacies of the British Empire. It helps to avoid stamping, unquestioned, on one generation, the morality, attitudes and social rules of the distant past. Lord Denning, as a leading judge, would have spoken up himself, as he always did with good humour to answer selected critics. As a court leader he would have encouraged a more effective response from the courts to communicate their decisions to the public and to explain their techniques and the necessities of occasional judicial creativity. He would have urged the Bar and other members of the legal profession to take a lead in responding to unmerited attacks on the judiciary who, as he once pointed out, are generally not well placed to answer back. He would have called for mutual respect between the branches of government as each branch performs the functions proper to itself. He would have encouraged

${ }^{75}$ See e.g. Judicial Officers Act 1986 (N.S.W.) which establishes a Conduct Division to receive, investigate and determine certain complaints against judicial officers in New South Wales. 
a return to the education of the citizenry in civics so that they would understand their national constitution and the vital role of the judges in its scheme.

The judges of today who follow as lineal descendants in the common law judiciary, can take strength from the fortitude of Lord Denning, his good humour in the face of criticism and Lordly rebukes, his faithful adherence to principles of free speech ${ }^{76}$ and his unapologetic dedication to refurbishing the common law, as his great predecessors had done before him. When, like Lord Denning, one has a perspective of a century, the gales of abuse are seen for what they are. Passing things. The storms come and go. The judicial institution goes on. The judges continue to make their decisions with obedience to statutory law as they construe it and faithful reliance upon legal authority as they define it but with the stimulation of legal principle and legal policy where that is needed to avoid plain injustice and to reverse a wrong turning.

Lord Denning weathered the storms of his time when he was occasionally criticised for activism. Our societies have continued to change. His example is unchanging. He remains a great encouragement to us to remember the basic character of our calling.

We, his successors throughout the world, are not mechanics of the law. We are a profession sworn to justice. That is what gives the law its claim to moral nobility. This remains Denning's great instruction to us. Even when the din of attack, the superficial political labels and the pressure of criticism become most vocal (perhaps especially then) the independent judges of the common law must remain steadfast and self-confident in their vocation. The times have changed significantly since Denning served as a judge. It is given to few to serve as long or as brilliantly. But every judicial officer of the common law, high and low, is reminded by Denning's life and work that creativity is part of the genius of our vocation. We must explain this to each succeeding generation of lawyers, as Denning, by his example and ceaseless efforts, tried to do. We must seek to explain it to citizens beyond the courtroom so that, like Denning, they honour and cherish the common law. We must remember it for ourselves

\footnotetext{
${ }^{76}$ A. T. Denning, Freedom under the Law (Hamlyn Lectures, Stevens \& Co., 1949), Williams, supra n. 16 at p.119.

${ }^{77}$ Oceanic Sunline Special Shipping Co. Inc. v. Fay (1988) 165 C.L.R. 197 at 252; cf. Northern Territory v. Mengel (1995) 185 C.L.R. 307 at 347.
} 